\title{
Implementation of Goal Ii of Cop21 Until 2030
}

\author{
Jan-Erik Lane \\ 10 Charles Humbert 1205 Geneva
}

*Corresponding Author: Jan-Erik Lane, 10 Charles Humbert 1205 Geneva

\begin{abstract}
Halting climate change is an enormous coordination task for international governance where the major state powers play a major role, including the risk of defection. The 2015 Paris enactment of the COP21 Treaty with its three objectives is considered as the chief response to the set of challenges that global warming presents to mankind in this century. Will the COP21 framewotk suffice? Let us ask: What more exactly is involved the implementation of the GOAL II, i.e. the reduction of CO2s up to 2030?
\end{abstract}

Keywords: Decarbonisation, COP21: GOAL I, II And III, Solar Power Plants, Ouarzazate Type Size.

\section{INTRODUCTION}

The COP21 community is an example of a common pool regime, the CPRs of Ostrom (1990). This global ecology club now debates about the consequences of the US defection from the COP21 Treaty, but things are moving on in real life, as the Keeling curve displaces its relentless rise of $\mathrm{CO} 2 \mathrm{ppm}$. The optimists about climate change argue that the objectives of COP21 are still within reach, especially if GOAL I is implemented now - no more augmentation of $\mathrm{CO} 2$ emissions. Yet, the pessimists point out that the $\mathrm{CO} 2 \mathrm{~s}$ in the atmosphere keeps augmenting. We are now close to $410 \mathrm{ppm}$ on the Keeling curve (Earth $\mathrm{CO} 2$ ).

The optimists underline the many micro changes the recent years in energy production, efficiency and transformation. However, the pessimists emphasize that the macro picture remains much the same, globally speaking: more of air and sea transportation, coal replaced by oil and gas, the shale gas revolution, constantly more cars and bigger engines, wood coal and deforestation, reduction of the Amazons and Borneo forests, etc. Why has the recognition of climate change been so late and so contested by some groups?

\section{THEORY OF GLOBAL WARMING}

A scientific theory is a set of hypotheses that can be falsified. The growth of knowledge consists in the build-up of hypotheses until they form a core model. The first anticipation of the global warming mechanism was done by famous mathematician Frenchman Joseph Fourier in the early $19^{\text {th }}$ century, but the theory was developed by Swedish chemist Arrhenius around 1895. He calculated that a doubling of $\mathrm{CO} 2 \mathrm{ppm}$ would be conducive to a 5 degree increase in global average temperature, an exaggeration at that time. But Arrhenius is not too far off the worst case scenario for the 21 rst century, according to UN expertise now.

Yet, it was not until Stephen Schneider published Global Warming in 1989 that the theory started to receive wide attention with his journal Climate Change, no doubt strengthened by the work of Keeling in the 1960 and 70s in measuring CO2 ppm globally. Moreover, techniques for viewing the CO2 layer were developed, increasing the attention to climate change.

In the 1990s, the UN reacted with creating a few bodies to look into the changes going on, one of which was the COP framework with the UNFCCC inter alia. Thereafter, economists jumped in besides the natural scientists, worried about the future costs of this transformation of the atmosphere. On the one hand, Kaya and associates presented a model that explained $\mathrm{CO} 2$ :s with anthropogenic need for energy and the energy intensity of GDP - especially fossil fuels. On the other hand, Stern called global warming the largest externality in human history, calling for international governance in order to stem the growth of greenhouse gases. Stern outlined in 2007 a number of activities aimed at reducing $\mathrm{CO} 2$ emissions, promising also a Super Fund to channel money from rich advanced nations 
to poor countries and developing economies. As little has been done through the UN system of meetings and agencies - transaction costs - up to date, Stern in 2015 asked: "What are we waiting for?"

All theories - also climate change hypotheses - need confirmation. When the polar ice mountains began to collapse, it seemed decisive evidence for the global warming theory. Other important test implications like glacier retreats everywhere, ocean warming and acidification as well as desertification in Africa also gave support for global warming theory. Denials of climate change appear more and more unfounded, although it is true that more of $\mathrm{CO} 2$ may benefit some fauna or environment niches. For those interested in the debate over the cognitive status of global warming theory, they can contrast the articles in Sceptical Science with those in Science CO2.

\section{RISKS FROM HUMAN INDUCED CLIMATE CHANGE}

Considering the probable damages from global warming, it is astonishing that global warming theory has not been better recognized or even conceptually developed or empirically corroborated. If global warming continues unrestrained, much of Asia will be negatively affected, just as Australia is on the verge of losing its coral reefs. There will be sooner or later:

a. Huge land losses along the costs;

b. Too high temperatures for men and women to work outside;

c. Food production decline;

d. Fish harvest decrease;

e. Droughts and starvation;

f. Lack of fresh water supply;

g. Drying up of rivers, affecting electricity supply;

h. Ocean acidification and species extinction;

i. Highly volatile climate with tremendous damages.

This list is far from complete or exhaustive. One could even mention worse outcomes, like the transformations of warm and cold currents in the oceans - the Gulf Stream and North Atlantic Current. What one may underline is that so far no known really important negative feedback has been found that could stem global warming naturally. We seem to have mainly only positive feedbacks, meaning outcomes reinforce each other in the same direction. The situation in the Amazons and Borneo is basically "lost", and Siberian forests are under grave threat.

\section{ENERGY-ENVIRONMENT CONUNDRUM}

All forms of energy be measured, and these measures are translatable into each other - a major scientific achievement. One may employ some standard sources on energy consumption and what is immediately obvious is the huge numbers involved - see Table 1 .

Table1. Energy Consumption 2015 (Million Tons Of Oil Equivalent)

\begin{tabular}{|l|l|l|}
\hline & Total & $\%$ \\
\hline Fossil fuels & 11306,4 & 86,0 \\
\hline Oil & 4331,3 & 32,9 \\
\hline Natural Gas & 3135,2 & 23,8 \\
\hline Coal & 3839,9 & 29,2 \\
\hline Renewables & 1257,8 & 9,6 \\
\hline Hydroelectric & 892,9 & 6,8 \\
\hline Others & 364,9 & 2,8 \\
\hline Nuclear power & 583,1 & 4,4 \\
\hline Total & 13147,3 & 100,0 \\
\hline
\end{tabular}

Source: BP Statistical Review of World Energy 2016

Basically, roughly 90 per cent of all energy consumption comes from non-renewables. The COP21 call for decarbonisation involves a sharp reduction of fossil fuels up until 2030 in order to stabilize climate change with a 30-40 decrease in $\mathrm{CO} 2$ emissions. Let us focus upon what this hoped for reduction of fossil fuels implies for the augmentation of renewable energy consumption, here solar 
power. The use of atomic power is highly contested, some countries closing reactors while others construct new and hopefully safer ones. I here bypass wind power and thermal power for the sake of simplicity in calculations. I deal only with the COP21 GOAL II, which entails real reductions in CO2 emissions. The GOAL III, promisiong complete decarbonisation by 2070, is just utopian.

\section{IMPLICATIONS OF COP21 FOR GOAL II}

Consider now Table 2, using the giant solar power station in Morocco as the benchmark - How many would be needed to replace the energy cut in fossil fuels and maintain the same energy amount, for a few selected countries with big $\mathrm{CO} 2$ emissions?

Table2. Number of Ouarzazate size power plants required up to 2030 for GOAL II

\begin{tabular}{|l|l|l|l|}
\hline Nation & $\begin{array}{l}\text { Co2 reduction pledge / } \\
\text { \% of 2005 emissions }\end{array}$ & $\begin{array}{l}\text { Number of gigantic solar } \\
\text { plants needed (Ouarzazate) }\end{array}$ & $\begin{array}{l}\text { Gigantic plants needed } \\
\text { for 40 \% reduction }\end{array}$ \\
\hline United States & $26-28^{1}$ & 2170 & 3100 \\
\hline China & none $^{2}$ & 0 & 3300 \\
\hline EU28 & $41-42$ & 2300 & 2200 \\
\hline India & none $^{2}$ & 0 & 1700 \\
\hline Japan & 26 & 460 & 700 \\
\hline Brazil & 37 & 170 & 190 \\
\hline Indonesia & 29 & 120 & 170 \\
\hline Canada & 30 & 230 & 300 \\
\hline Mexico & 25 & 120 & 190 \\
\hline Australia & $26-28$ & 130 & 190 \\
\hline Russia & none & 0 & 940 \\
\hline World & $\mathrm{N}^{3}$ & N/A & 16200 \\
\hline
\end{tabular}

Note: Average of 250 - 300 days of sunshine used for all entries except Australia, Indonesia, and Mexico, where 300 - 350 was used). 1 America pulled out from the deal in June 20172 China and India has only made pledges in terms of CO2 emissions per GDP, not absolute targets.

Sources: Paris 2015: Tracking country climate pledges. Carbon Brief, https://www.carbonbrief.org/paris-2015tracking-country-climate-pledges; EDGAR v 4.3.2, European Commission, Joint Research Centre (JRC)/PBL Netherlands Environmental Assessment Agency. Emission Database for Global Atmospheric Research (EDGAR), release version 4.3.2. http://edgar.jrc.ec.europe.eu, 2016 forthcoming; CO2 Emission Reduction with Solar

http://www.solarmango.com/in/tools/solar-carbon-emission-reduction

Even if some of the solar power will be generated from solar roof panels on many, many small houses, the task of generating sufficient electricity for maintaining present standards of living is herculean, for the nations above and other countries as well, most probably.A few of the nations above will augment nuclear power, building such plants ambitiously like China, South Korea and India. At the same time, other nations cancel out their nuclear dependency wholly or partially, like Japan, Germany, France and Sweden. Brazil hopes for much more of hydro power, despite that water shortages appear around the globe, also in South America. Atomic power is non-renewable but extremely efficient, giving rise to other kinds of environmental-pollution problems.

When taking into account that global planning speak of a 20-30 per cent increase in energy for the coming decades, and then one understands the Schneider's ominous projection: This century may well be the greenhouse period of mankind.

\section{Co2 Emissions And Temperature Change}

One may attempt to calculate exactly how increases in greenhouse gases impact upon temperature augmentations. Take the case of $\mathrm{CO} 2 \mathrm{~s}$, where a most complicated mathematical formula is employed:

\footnotetext{
${ }^{1}$ America pulled out from the deal in June 2017

${ }^{2}$ China and India has only made pledges in terms of CO2 emissions per GDP, not absolute targets

${ }^{3}$ Russia made pledge of 25 - $30 \%$ compared to 1990 levels, but this has already been met due to a shrinking economy

${ }^{4}$ Unclear sum of all countries pledges, several nations have interval in their commitments.
} 
1. $T=T c+T n$, where $T$ is temperature, $T c$ is the cumulative net contribution to temperature from $\mathrm{CO} 2$ and $\mathrm{Tn}$ the normal temperature;

But when it comes to methane, it is not known whether the tundra will melt and release enormous amounts. But methane does not stay in the atmosphere long, like CO2s. For the other greenhouse gases, there is no similar calculation as for the CO2s: If humans could eat less meat from cows, it would mean a great improvement, as more than a billion cows emit methane. Food from chicken should replace beef meat and burgers. The general formula reads:

2. $d T=\lambda^{*} d F$, where 'dT' is the change in the Earth's average surface temperature, ' $\lambda$ ' is the climate sensitivity, usually with degrees Celsius per Watts per square meter $\left({ }^{\circ} \mathrm{C} /[\mathrm{W} / \mathrm{m} 2]\right)$, and ' $\mathrm{dF}$ ' is the radiative forcing.

To get the calculations going, we start from lambda between 0.54 and 1.2, but let's take the average $=$ 0.87 . Thus, we have the formula (Myhre el al, 1998):

Formula: $0.87 \times 5.35 \times \ln (\mathrm{C} / 280)$.

Figure1. shows how $\mathrm{CO} 2$ emissions may raise temperature to 4-5 degrees, which would be Hawking's worst case scenario.

\section{CO2 atmospheric concentration vs. Rise in global temperature}

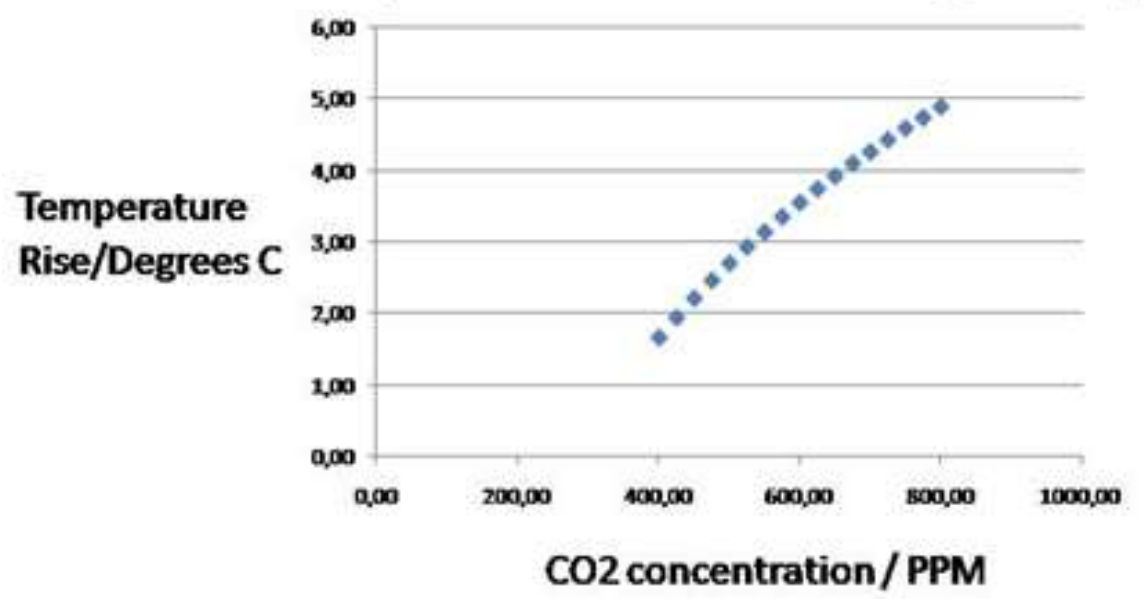

Figure1. Co2s and Temperature Rise in Celcius

No one knows where the critical temperature rise occurs, i.e. from which Celsius degree global warming becomes "irreversible", to use Stephen Hawking's expression. It could be as low as +2 Celsius or as high as +5 Celsius.

There are several greenhouse gases, but the two biggest are the $\mathrm{CO} 2 \mathrm{~s}$ and methane. The UNFCCC has concentrated upon halting and reducing carbon dioxide, but now we are about to face a methane threat. Table 3 shows that methane is growing faster than $\mathrm{CO} 2$.

Table3. Ghc Minus Co2s

Year GHG other than CO2 / Tton

\begin{tabular}{|c|c|}
\hline 1990 & 15,56 \\
\hline 1995 & 15,20 \\
\hline 2000 & 14,74 \\
\hline 2005 & 17,20 \\
\hline 2010 & 17,05 \\
\hline 2011 & 18,47 \\
\hline 2012 & 18,97 \\
\hline
\end{tabular}

Source: EDGARv4.2FT2012, European Commission, Joint Research Centre (JRC)/PBL Netherlands Environmental Assessment Agency. Emission Database for Global Atmospheric Research (EDGAR), release version 4.2

Figure 3 displays the explosive increase in methane emissions, the consequenecs of which are far from fully known. 


\section{Methane emissions/ (kt CO2 equivalent)}

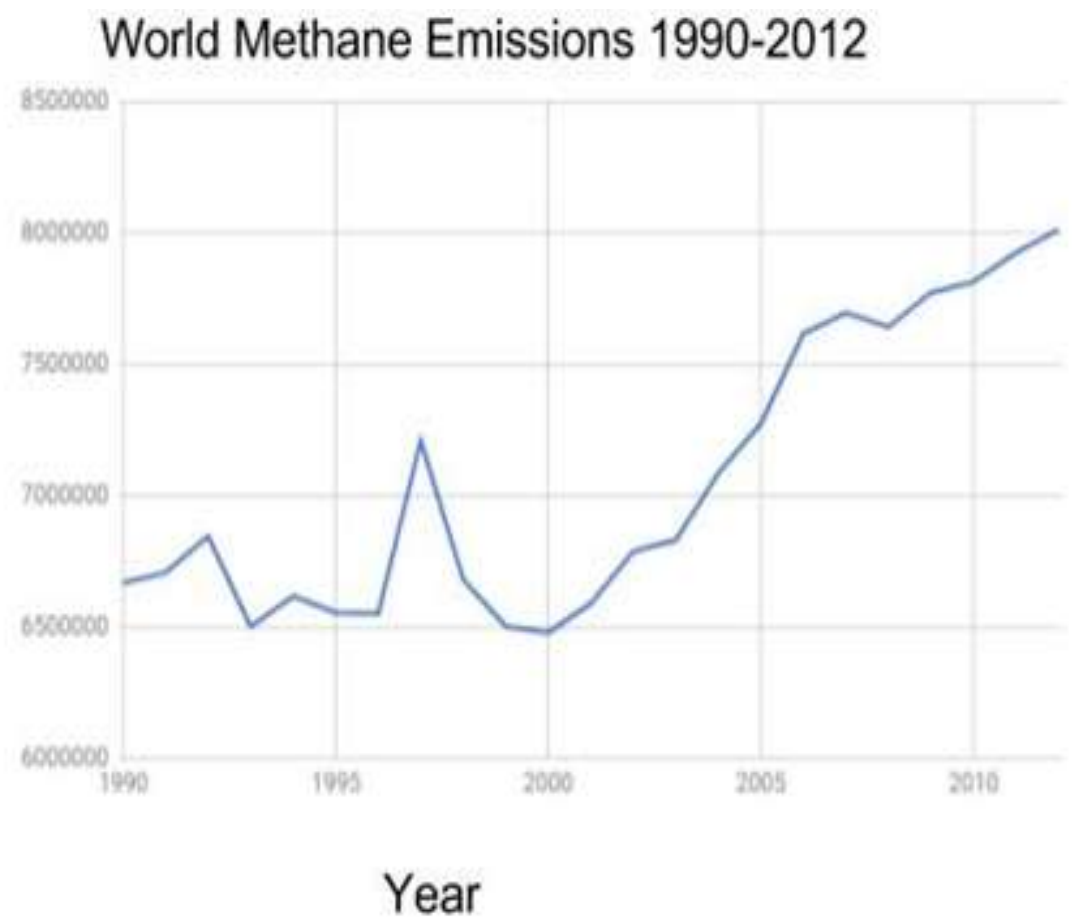

Figure3. Methane Emissions

Source: World Bank Data Indicators

The threat from global warming due to methane must be taken most seriously, as methane may be released by the now accelerating melting of the permafrost. The UNFCCC must start paying more attention to other GHGs than only the CO2s.

\section{CONCLUSION}

It is high time not only to abide by GOAL I, i.e. stop the increase in $\mathrm{CO} 2$ emissions. A few countries have accomplished this already, but several are still on the growth line. Yet, it GOAL II that posits the unique challenge to all countries. We have shown here what replacing existing fossil fuels energy consumption with renewables (solar power here) entails up to 2030. It requires massive investments, but the economies in the world are mostly debt stricken while governments and energy producers plan for a large increase in energy consumption. It just does not add up, not even for advanced capitalist countries in Europe - see Table 4.

Table4. Number of Ouarzazate size power plants required up to 2030 for GOAL II

\begin{tabular}{|l|l|l|l|}
\hline \multicolumn{1}{|c|}{ Nation } & \multicolumn{1}{|c|}{$\begin{array}{c}\text { Co2 reduction pledge / } \\
\text { \% of 2005 emissions }\end{array}$} & $\begin{array}{c}\text { Number of gigantic solar } \\
\text { plants needed (Ouarzazate) }\end{array}$ & $\begin{array}{c}\text { Gigantic plants needed } \\
\text { for 40 \% reduction }\end{array}$ \\
\hline Germany & $49^{5}$ & 550 & 450 \\
\hline France & $37^{1}$ & 210 & 220 \\
\hline Italy & $35^{1}$ & 230 & 270 \\
\hline Sweden & $42^{1}$ & 30 & 30 \\
\hline
\end{tabular}

(Average of 250 - 300 days of sunshine per year was used).

Sources: Paris 2015: Tracking country climate pledges. Carbon Brief, https://www.carbonbrief.org/paris-2015tracking-country-climate-pledges; EDGAR v 4.3.2, European Commission, Joint Research Centre (JRC)/PBL Netherlands Environmental Assessment Agency.Emission Database for Global Atmospheric Research (EDGAR), release version 4.3.2. http://edgar.jrc.ec.europe.eu, 2016 forthcoming; CO2 Emission Reduction With Solar

http://www.solarmango.com/in/tools/solar-carbon-emission-reduction

Interestingly, also advanced European countries face huge tasks in decarbonisation, according to GOAL II. They need to turn massively to renewables while at the same time reducing atomic power wholly or partially. Is this really doable or realistic?

\footnotetext{
${ }^{5}$ EU joint pledge of $40 \%$ compared to 1990
} 


\section{REFERENCES}

\section{GDP SOURCES}

[1] World Bank national accounts data - data.worldbank.org

[2] OECD National Accounts data files

\section{GHG AND ENERGY SOURCES}

[3] World Resources Institute CAIT Climate Data Explorer - cait.wri.org

[4] EU Joint Research Centre Emission Database for Global Atmospheric

[5] Research - http://edgar.jrc.ec.europa.eu/overview.php

[6] UN Framework Convention on Climate Change -

[7] http://unfccc.int/ghg_data/ghg_data_unfccc/time_series_annex_i/items/3814.php

[8] International Energy Agency. Paris.

[9] Energy Information Administration. Washington, DC.

[10] BP Energy Outlook 2016.

[11] EU Emissions Database for Global Research EDGAR,

[12] http://edgar.jrc.ec.europa.eu/

[13] World Bank Data Indicators, data.worldbank.org

[14] British Petroleum Statistical Review of World Energy 2016

\section{LITERATURE}

[15] "Arrhenius, Svante August" in Chambers' Encyclopedia. London: George Newness, 1961, Vol. 1.

[16] Kaya, Y. and Yokoburi, K. (1997) Environment, energy, and economy: Strategies for sustainability. Tokyo: United Nations University Press.

[17] Ostrom, E. (1990) Governing the Commons. Cambridge: CUP.

[18] Schneider, S. (1989) 'Global Warming: Are We Entering the Greenhouse Century?' San Francisco: Sierra Club.

[19] Stern, N. (2007) the Economics of Climate Change. Oxford: OUP.

[20] Stern, N. (2015) what are we waiting for? Cambridge, MA: MIT Press.

Citation: Jan-Erik, Lane. "Implementation of Goal Ii of Cop2 Until 2030." International Journal of Managerial Studies and Research (IJMSR), vol 5, no. 9, 2017, pp. 51-56. doi:http://dx.doi.org/10.20431/23490349.0509009.

Copyright: (C) 2017 Authors. This is an open-access article distributed under the terms of the Creative Commons Attribution License, which permits unrestricted use, distribution, and reproduction in any medium, provided the original author and source are credited. 